\title{
Sensitivity of Rhonegletscher, Switzerland, to climate change: experiments with a one-dimensional flowline model
}

\author{
Jakob Wallinga, Roderik S.W. van de Wal \\ Institute for Marine and Atmospheric Research, Utrecht University, P.O. Box 80005, 3508 TA Utrecht, The Netherlands
}

\begin{abstract}
A one-dimensional time-dependent flowline model of Rhonegletscher, Switzerland, has been used to test the glacier's response to climatic warming. Massbalance variations over the last 100 years are obtained from observations of the equilibrium-line altitude (ELA) and a reconstruction of the ELA based on a statistical correlation between temperature and ELA. For the period prior to AD 1882, for which no reliable climate data exist, we chose equilibrium-line altitudes that enabled us to simulate accurately the glacier length from $\mathrm{AD} 1602$.

The model simulates the historical glacier length almost perfectly and glacier geometry very well. It underestimates glacier-surface velocities by $1-18 \%$. Following these reference experiments, we investigated the response of Rhonegletscher to a number of climate-change scenarios for the period AD 1990-2100. For a constant climate equal to the 1961-90 mean, the model predicts a $6 \%$ decrease in glacier volume by AD 2100 . Rhonegletscher will retreat by almost $1 \mathrm{~km}$ over the next 100 years at this scenario. At a warming rate of $0.04 \mathrm{~K} \mathrm{a}^{-1}$, only $4 \%$ of the glacier volume will be left by AD 2100 .
\end{abstract}

\section{INTRODUCTION}

Roughly one-third of the total expected sea-level rise in the next 100 years will be due to the melt of valley glaciers and small ice caps (Warrick and others, 1996). The attempts to estimate the contribution of valley glaciers and ice caps to sea-level rise are fairly simple compared to the estimates of the contribution of thermal expansion and the contributions of Antarctica and Greenland, the other major components of sea-level change on a time-scale of a 100 years. It is vitally important that simple, yet realistic, models which include processes linking meteorology to mass balance and dynamic response be developed (e.g. Meier, 1965; Greuell, 1992; Warrick and others, 1996). Since the geometry and climatic setting of valley glaciers vary enormously, studies will have to concentrate on as many different glaciers as possible. Unfortunately, insufficient data are available for every glacier. Mass-balance data and information concerning the bedrock of glaciers are sparse.

In this paper, Rhonegletscher is simulated using a onedimensional, time-dependent flowline model. Similar models (with varying description of geometry and flow parameters) have been developed for Griesgletscher (Bindschadler, 1981), for Variegated Glacier (Bindschadler, 1982), for Lewis Glacier (Kruss, 1983, 1984), for Nigardsbreen (Oerlemans, 1986), for Glacier d'Argentière (Huybrechts and others, 1989), for Rhonegletscher (Stroeven and others, 1989), for Hintereisferner (Greuell, 1992), for Pasterze (Zuo and Oerlemans, 1997) and for Unterer Grindelwaldgletscher (Schmeits and Oerlemans, 1997). The relatively simple flow models used in the above-mentioned studies (no longitudinal stresses included) will not reproduce the dynamic behaviour of those glaciers in all detail. However, the success of most simple continuity considerations for long time periods indicates that details of dynamic flow are by far surpassed in importance by simple mass redistribution at climatological relevant time-scales.

This paper presents how Rhonegletscher will respond to several temperature and precipitation scenarios for the next 100 years. After Stroeven and others (1989) published their work on Rhonegletscher, new mass-balance and climatological data became available. Stroeven and others (1989) used a mass-balance forcing with fixed mass-balance gradients related to climatic series from tree-ring widths from Germany (Lamb, 1977), central England summer-temperature data (Lamb, 1977), the "Basler Temperaturreihe" (Bider and others, 1959; Burkhardt and Hense, 1985) and temperature and precipitation data for the whole of Switzerland (Pfister, 1984).

In this paper, the mass balance of Rhonegletscher is based on data presented by Chen and Funk (1990) and Müller-Lemans and others (1995). Chen and Funk (1990) presented mass-balance data for the periods 1884-1909 and 1979-81. Müller-Lemans and others (1995) presented temperature and precipitation records from nearby meteorological stations for the period 1882-1987. These two papers enabled us to reconstruct the mass-balance history of Rhonegletscher since 1882 based on a statistical relation between equilibrium-line altitudes and observed temperature records from nearby weather stations. This approach yields a more reliable mass-balance reconstruction for the period 1882-1990 than the reconstructions attempted by Stroeven and others (1989). For the period prior to 1882, the mass-balance forcing is derived indirectly from the length record by dynamic calibration (Oerlemans, 1997).

This improved mass-balance reconstruction resulted in a good simulation of the present-day geometry, a prerequisite for estimating the future response of the glacier, which was not satisfied by the work of Stroeven and others (1989). This enabled us to impose temperature and precipitation 
scenarios for the next 100 years and to calculate the volume of the glacier as a function of time using the same procedure as carried out for several other glaciers within the framework of the European Ice Sheet Modelling Initiative (EISMINT) glacier intercomparison (Oerlemans and others, 1998).

\section{RHONEGLETSGHER}

Rhonegletscher is situated in the middle of the Swiss Alps $\left(46^{\circ} 37^{\prime} \mathrm{N} ., 08^{\circ} 24^{\prime} \mathrm{E}\right)$. It is the source of the River Rhone. A detailed map of Rhonegletscher is shown in Figure 1. Properties of Rhonegletscher are given in Table 1. The distance from the glacier's head, glacier length and average surface slope are measured along the flowline.

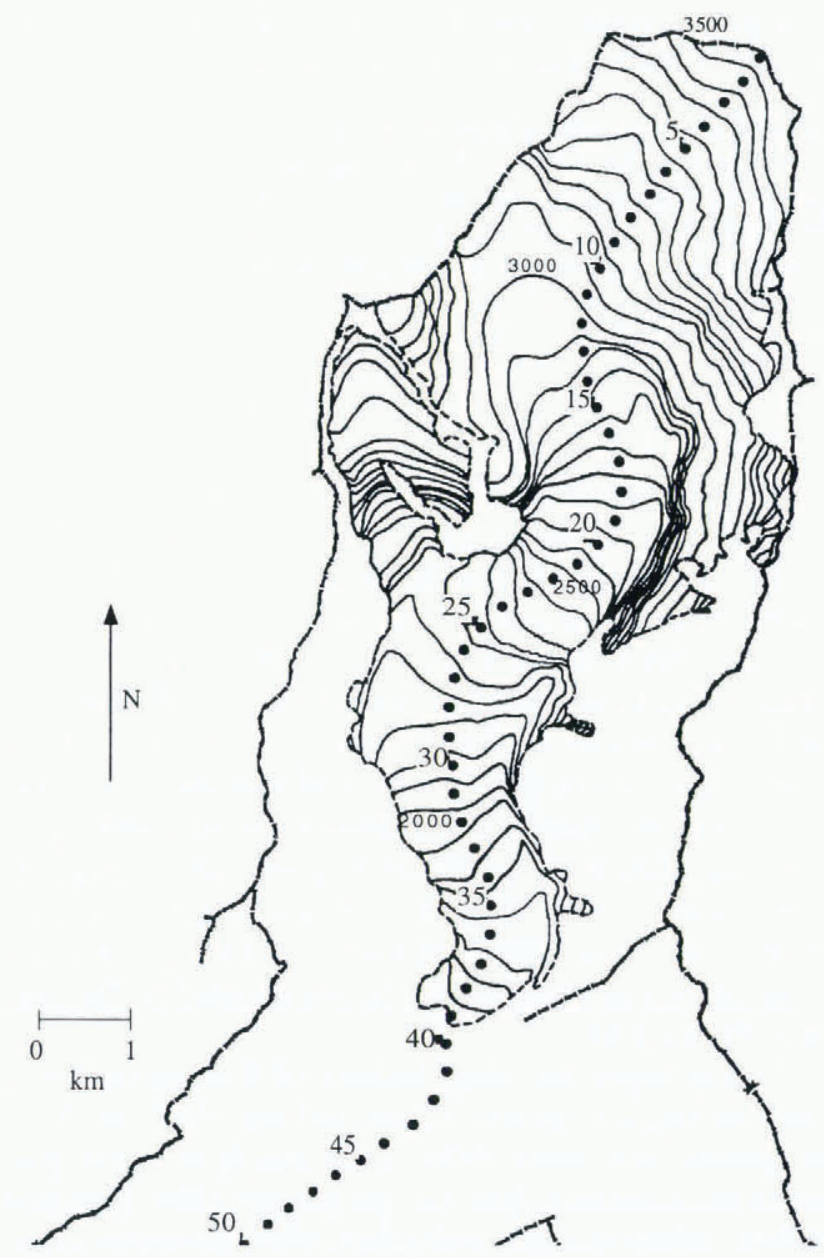

Fig. 1. Rhonegletscher in detail. Shown are the elevation contours and the flowline with grid points used for the model . Watersheds are indicated by thick dashed lines. Adapted from Stroeven and others (1989).

The main reason for choosing Rhonegletscher for this study is the long historical length record (Fig. 2). The length of Rhonegletscher has been recorded since AD 1602 (Kasser, 1967, 1973; Müller, 1977; Aellen, 1981; Haeberli, 1985; Haeberli and Müller, 1988; Haeberli and Hoelzle, 1993). Surface geometry of Rhonegletscher was recorded in 1969 (topographic map 1: 25000 of the Swiss Federal Topographical Survey; issued 1973) (Fig. 3). The mass balance and surface velocity were measured on Rhonegletscher in the period 1884-1908 (Mercanton, 1916; Chen and Funk, 1990). Mass-balance measurements were also performed in the period 1979-81
Table 1. Geometry and topography of Rhonegletscher in AD 1990

\begin{tabular}{lcl}
\hline Property & Value & Source \\
\hline Length & $9684 \mathrm{~m}$ & Haeberli and Hoelzle, 1993 \\
Altitude range & $2130-3520 \mathrm{~m}$ a.s.l. & \\
EL.A (1961-90 mean) & $2942 \mathrm{~m}$ a.s.l. & Reconstructed; this study \\
Surface area & $17.13 \mathrm{~km}^{2}$ & Model; this study \\
Volume estimate & $2.59 \mathrm{~km}^{3}$ & Model; this study \\
Mean thickness estimate & $150 \mathrm{~m}$ & Model; this study \\
Average slope & $14 \%$ & \\
Exposure & South & \\
& & \\
\hline
\end{tabular}

(Chen and Funk, 1990). Jost (1936) presented ice thickness for the lower part of Rhonegletscher based on seismic reflection. The bed profile for this lower section $(5.7-9.7 \mathrm{~km}$ from the head) is estimated by subtracting ice thickness from the 1930 s surface profile. The bed profile obtained resembles the

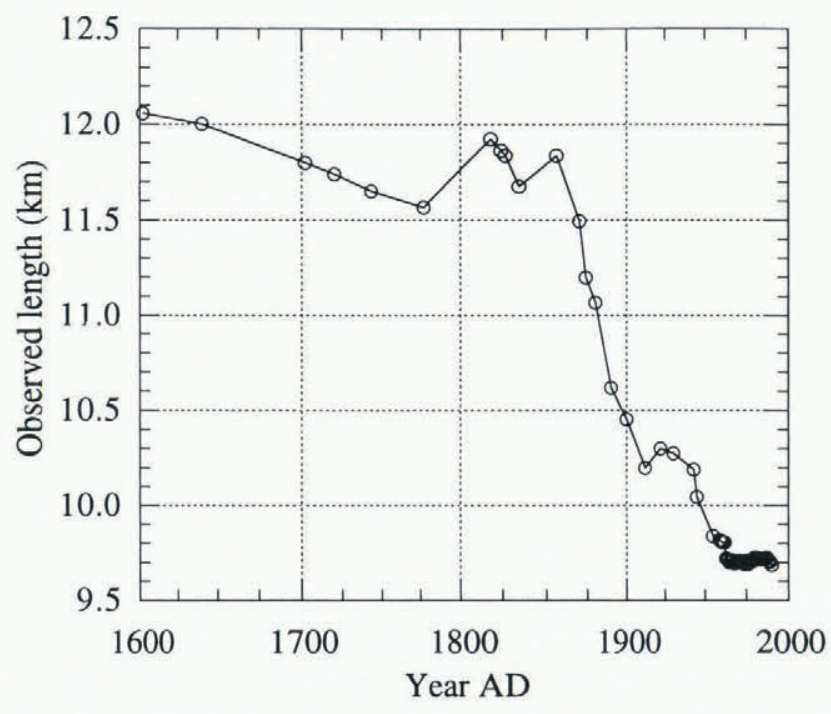

Fig. 2. The historical length record of Rhonegletscher. Data from Aellen (1981), Kasser (1967, 1973), Müller (1977), Haeberli (1985), Haeberli and Müller (1988), Haeberli and Hoelzle (1993). Circles are data points.

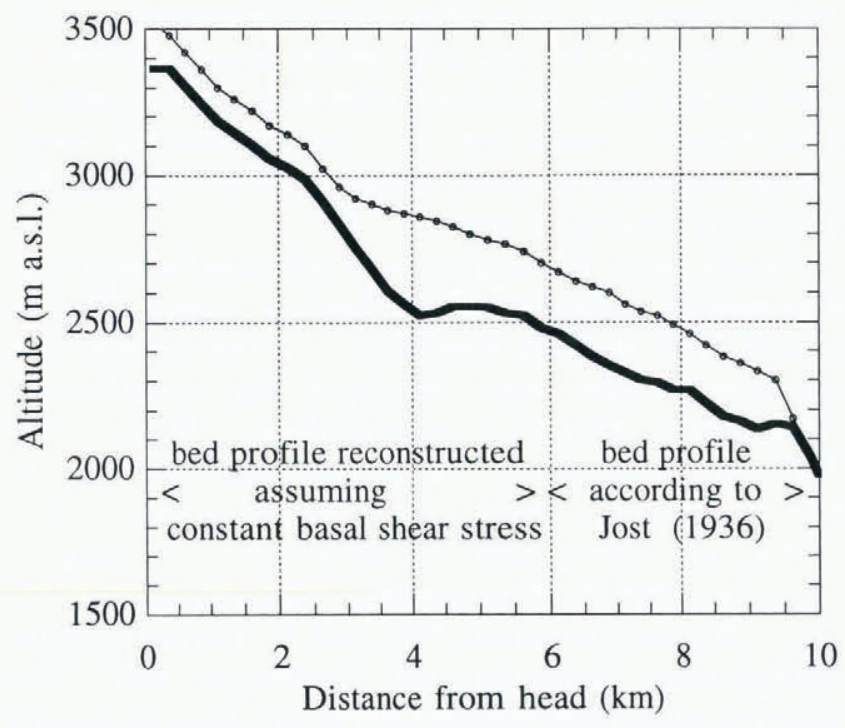

Fig. 3. The 1969 surface profile and the reconstructed bed profile of Rhonegletscher. Surface profile adapted from the 1: 25000 topographic maps of the Swiss Federal Topographical Survey. 
bed profile presented by Wächter (1983) on the basis of radio-echo soundings. Ice thickness in the upper part of the glacier has not been measured. In view of the available information, the best estimate for ice thickness for this part of the glacier is achieved assuming constant basal shear stress:

$$
\tau_{\mathrm{b}}=\rho g H \frac{\mathrm{d} h}{\mathrm{~d} x}=\text { constant. }
$$

Here, $\tau_{\mathrm{b}}$ is the basal shear stress (bar), $\rho$ is the density of ice $\left(900 \mathrm{~kg} \mathrm{~m}^{-3}\right), g$ is the acceleration of gravity $\left(9.8 \mathrm{~m} \mathrm{~s}^{-2}\right), H$ is the ice thickness $(\mathrm{m})$ and $\mathrm{d} h / \mathrm{d} x$ is the observed surface slope in 1969, with $x$ in the flow direction. $\tau_{\mathrm{b}}$ was estimated by a comparison of the estimated bedrock profile assuming constant basal shear stress and the constructed bedrock profile based on information from Jost (1936) for the lower part of the glacier. The adopted $\tau_{\mathrm{b}}$ is the average over a length of approximately 20 times the ice thickness. The best root mean square ( $\mathrm{rms}$ ) of the difference between the estimated and constructed bedrock profiles was obtained with a basal shear stress of 2.1 bar, which is in line with basal stresses estimated by Haeberli and Schweizer (1988) for the lower part of the 1850 Rhonegletscher. The value is higher than values given by Haeberli and Hoelzle (1995), partly because they incorporate a shape factor in the equation for the basal shear stress and because they assume a lower value for the average thickness of Rhonegletscher. For the transect from 2.75 to $5.5 \mathrm{~km}$ from the head of the glacier, we used a weighted smoothing $(70 \%)$ to obtain the final bedrock profile used in the model (Fig. 3). Note that the basal shear stress is only used to estimate the bedrock profile. The flow model includes variations in time and space of the basal shear stress.

\section{DESCRIPTION OF THE MODEL}

The model is one-dimensional (with the flowline along the $x$ axis) and is time-dependent. The time step used is 0.05 years, and grid-point spacing is $250 \mathrm{~m}$. The three-dimensional geometry is taken into account by parameterization of the cross-sectional geometry at each grid point. The cross-profile has a trapezoidal shape (Fig. 4) and is described by the valley width at the base $(W)$, bedrock height (b), and the average steepness of the valley walls on each side of the glacier $(\gamma)$, which yields two degrees of freedom for each grid point. Values for the width at the surface $\left(W_{\mathrm{s}}\right)$ and for $\gamma$ were taken from topographic maps. To keep distortion of the area/elevation ratio as small as possible, we used

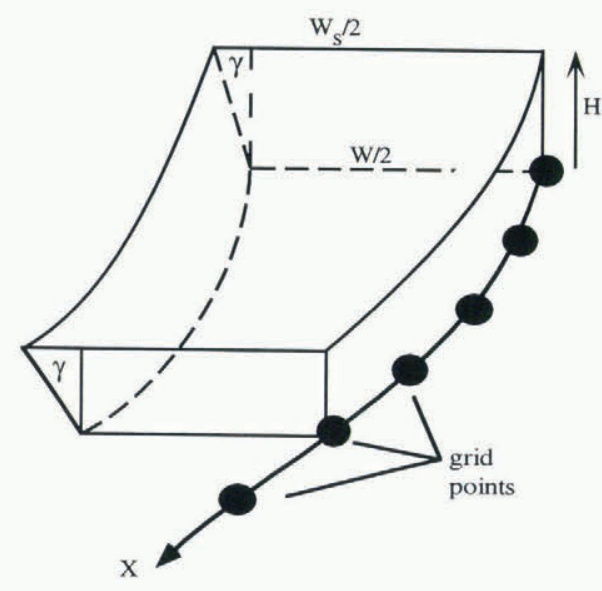

Fig. 4. Geometry for the glacier model. the length of the contour line passing through the grid point instead of the width perpendicular to the flowline. Expressions for the valley width at the base $(W)$ and the cross-sectional area of the glacier $(S)$ are:

$$
\begin{aligned}
W & =W_{\mathrm{s}}-2 \tan (\gamma) H \\
S & =[W+(\tan (\gamma) H)] H .
\end{aligned}
$$

The dynamic behaviour of the glacier is described in terms of changes in ice thickness, calculated from the continuity equation. Since ice density is assumed to be constant, the conservation equation for ice volume is used:

$$
\frac{\partial S}{\partial t}=-\frac{\partial}{\partial x}(U S)+B W_{\mathrm{s}} .
$$

Here, $U$ is the mean ice velocity at the cross-section and $B$ is the annual specific mass gain or loss. This equation expresses the notion that gain in the cross-sectional area is accounted for by the surplus of accumulation minus the loss of ice to adjacent parts of the glacier. Substitution of Equations (2) and (3) into Equation (4) yields:

$$
\begin{aligned}
& \frac{\partial H}{\partial t}=\frac{-1}{W+2 \tan (\gamma) H} \\
& {\left[(W+\tan (\gamma) H) \frac{\partial(U H)}{\partial x}+U H \frac{\partial}{\partial x}(W+\tan (\gamma) H)\right]+B .}
\end{aligned}
$$

The depth-averaged ice velocity $(U)$ is determined by internal deformation $\left(U_{\mathrm{d}}\right)$ and sliding $\left(U_{\mathrm{s}}\right)$. Variations in basal water pressure are not considered in this study, since they are not expected to be relevant in the light of other approximations made. The following equations are used to calculate the depth-averaged ice velocity (Budd and others, 1979; Paterson, 1981)

$$
\begin{aligned}
U=U_{\mathrm{d}}+U_{\mathrm{s}} & =f_{1} H \tau_{\mathrm{d}}^{3}+\frac{f_{2} \tau_{\mathrm{d}}^{3}}{\rho g} \\
\tau_{\mathrm{d}} & =-\rho g H \frac{\mathrm{d} h}{\mathrm{~d} x} .
\end{aligned}
$$

Here, $\tau_{\mathrm{d}}$ is the driving stress and $f_{1}$ and $f_{2}$ are the flow parameters. The flow parameters depend on bed conditions, debris content and crystal structure of the basal ice layers. Since the flow parameters are not known accurately, they are used as tuning parameters. It is assumed that Rhonegletscher is temperate, so that the flow parameters are constant in time. Near-surface frozen zones are therefore neglected.

The values adopted for the flow parameters are:

$$
\begin{aligned}
& f_{1}=3.17 \times 10^{-25} \mathrm{~m}^{6} \mathrm{~s}^{-1} \mathrm{~N}^{-3} \\
& f_{2}=9.51 \times 10^{-17} \mathrm{~m}^{5} \mathrm{~s}^{-1} \mathrm{~N}^{-2} .
\end{aligned}
$$

These values for the flow parameters are lower compared to flow parameters used in similar studies (e.g. Budd and others, 1979; Greuell, 1989) but turned out to yield the best results, as explained in section 5 .

Annual specific net balance $(B)$ for every point on the glacier is defined by the equilibrium-line altitude (ELA) and mass-balance gradients. These two properties are used as forcing and will be discussed in section 4 .

\section{INPUT DATA FOR FORGING THE MODEL}

\subsection{Equilibrium-line altitude}

The model is forced by the ELA and mass-balance gradi- 
ents $(\mathrm{d} B / \mathrm{d} z)$. Together, these two parameters provide massbalance values $(B)$ for every point on the glacier, following the equation:

$$
B=\frac{\partial b}{\partial z}(\mathrm{ELA}-h)
$$

The ELA on Rhonegletscher is known for the years 18841908 and for the years 1979-81 (Chen and Funk, 1990). Since the ELA has to be known for each year, we attempted to derive the ELA from meteorological observations. A reasonably good correlation was found between ELA and the mean summer (June-August) air temperature $\left(T_{\mathrm{s}}\right)$ from two nearby weather stations (Fig. 5). Temperature data from the weather stations Andermatt (1442 m a.s.1., $15 \mathrm{~km}$ northeast of Rhonegletscher) and Reckingen (1338 m a.s.l., $9 \mathrm{~km}$ south of Rhonegletscher) have been presented by MüllerLemans and others (1995) for the period 1882-1986. On the basis of a statistical rank-order correlation test, we omitted the years 1896 and 1908. With the remaining data, a reasonable correlation was achieved:

$$
\mathrm{ELA}=1414.5+127.0 T_{\mathrm{s}} \quad(n=26 ; r=0.79) .
$$

Here, $T_{\mathrm{s}}$ is the mean summer air temperature $\left({ }^{\circ} \mathrm{C}\right)$ from Andermatt and Reckingen, $n$ is the number of years used in the correlation and $r$ is the correlation coefficient. This statistical expression tells us that the ELA rises $127 \mathrm{~m}$ for every degree of increase in the summer air temperature. This is in line with findings for other glaciers (e.g. Oerlemans and Fortuin, 1992). Taking into account annual precipitation from both weather stations did not contribute to a better correlation. Cloudiness and surface albedo were not recorded in the period under study and could therefore not be used in our reconstruction. We reconstructed temperatures for the period 1987-90 using temperature data from Grimsel (1950 ma.s.l., $5 \mathrm{~km}$ southwest of Rhonegletscher) and Andermatt, so that we could extend the temperature record to 1990. The record from Grimsel is recalculated to

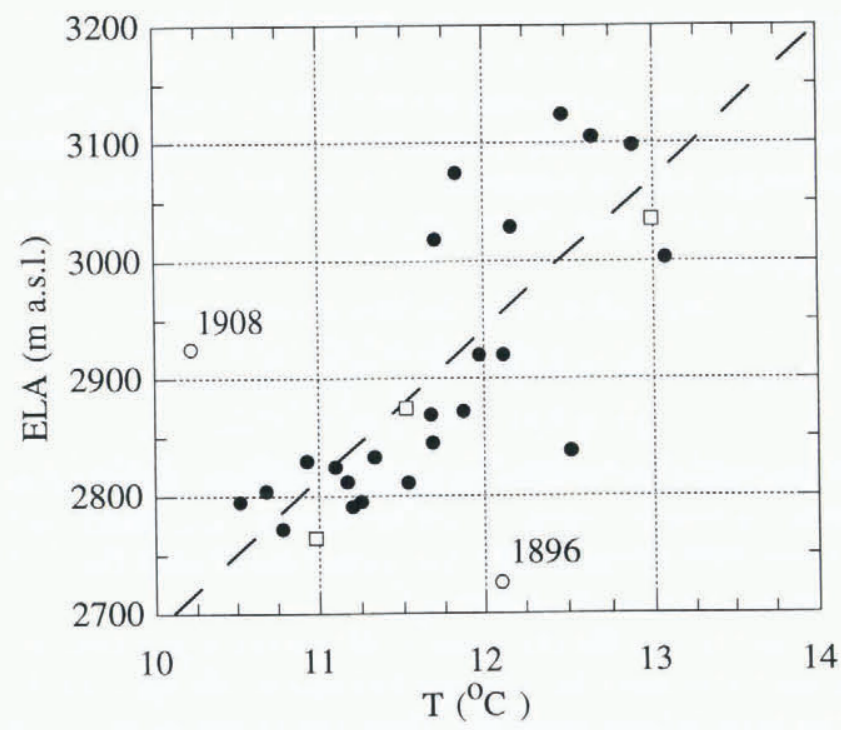

Fig. 5. Correlation between the mean summer (funeAugust) air temperature averaged from Reckingen and Andermatt weather stations (Müller-Lemans and others, 1995) and observed ELAs (Chen and Funk, 1990). Measurement periods are 1884-1908 (dots) and 1979-81 (squares). On the basis of a statistical rank-order correlation test, we did not use the measurements made in 1896 and 1908 in the correlation. data from Reckingen $\left(T_{\mathrm{R}}=T_{\mathrm{G}}+0.46\right)$ (personal communication from M. Funk, 1996).

With the correlation between ELA and temperature, we were able to reconstruct ELAs for Rhonegletscher for the period 1882-1990. Decadal mean ELAs were calculated using measured values where possible and reconstructed values if no measured values were available (Fig. 6).

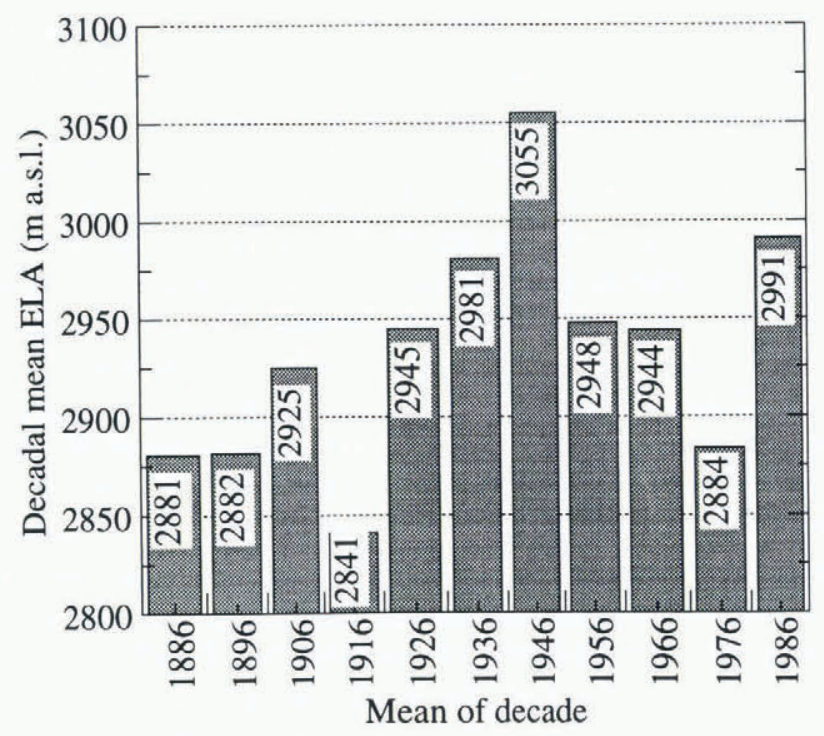

Fig. 6. Decadal mean ELA calculated from observations if present (Chen and Funk, 1990) and otherwise using the temperature ELA correlation presented in Equation (9).

\subsection{Mass-balance gradients}

Annual specific net-balance $(B)$ data for different altitude intervals of Rhonegletscher for the period 1884-1908 (period 1) and the period 1979-81 (period 2) have been presented by Chen and Funk (1990). We omitted values interpolated or extrapolated by Chen and Funk (1990), because values for period 1 were obtained using mass-balance gradients from period 2. We disagree with the interpolation and extrapolation techniques used by Chen and Funk (1990), because mass-balance gradients may change over time.

To achieve mass-balance gradients $(\mathrm{d} B / \mathrm{d} z)$, we plotted all mass-balance values relative to the measured ELA of the year in which they were measured (Fig. 7). The two measurement periods were examined separately. Three altitude intervals were taken separately: (1) accumulation zone; (2) ablation zone, between $2100 \mathrm{~m}$ a.s.l. and the ELA; (3) ablation zone below $2100 \mathrm{~m}$ a.s.l.. This last interval was taken separately because observations in period 1 show a higher ablation gradient for the tongue of the glacier, below $2100 \mathrm{~m}$ a.s.l. We think that this is a consequence of lateral warming from the main valley bottom and more pronounced exposure. The results are given in Table 2. Unfortunately, there is too short a monitoring period to validate the statistical relationships over an independent verification period. The statistical relationships are far from perfect, probably because important parameters like local precipitation, cloudiness and surface albedo are not known, and therefore could not be taken into account.

The mass-balance gradient in the accumulation zone in period 1 is thought to be unreliable, because mass balance was only measured in the lower accumulation area and 

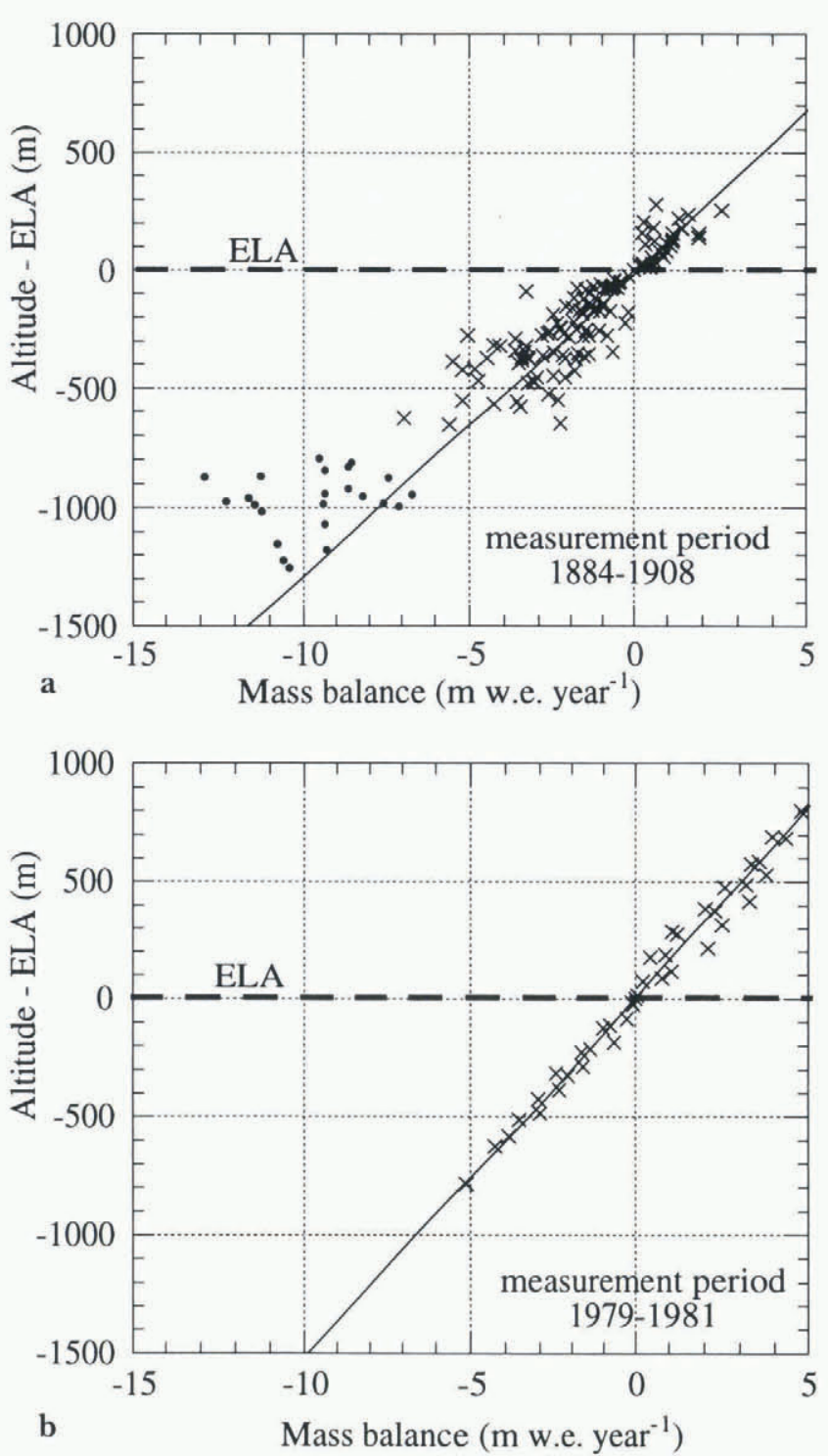

Fig. 7. Mass-balance measurements for the period $1884-1908$ (a) and for the period 197981 (b). Indicated are the regressions for the accumulation zone and for the ablation zone above $2100 m$ a.s.l. (indicated by crosses). Since measurements below $2100 \mathrm{~m}$ a.s.l. (indicated by dots) nearly all show more ablation than expected from the regression for the upper ablation area, a higher mass-balance gradient was used for the zone below 2100 ma.s.l. Data from Chen and Funk (1990). because the correlation coefficient is low. Furthermore, no measurements were made in the interval below $2100 \mathrm{~m}$ a.s.l. during period 2, because the glacier hardly reached this interval. To obtain mass-balance gradients for these two intervals, the ratio of the mass-balance gradients for each interval for periods 1 and 2 is assumed to be constant. We used the mass-balance gradients in the ablation zone above $2100 \mathrm{~m}$ a.s.l. to determine the ratio between period 1 and period 2 mass-balance gradients, because this interval showed good correlation for both periods. The calculated regression lines are shown in Figure 7 and the applied mass-balance gradients are given in Table 2.

The values presented here vary considerably from those given by Chen and Funk (1990). Differences in mass-balance gradients for period 1 are a consequence of the interpolation and extrapolation techniques used by Chen and Funk (1990). The reason for the differences in the ablation zone in period 2 is not clear.

In the model, the vertical mass-balance gradients are interpolated linearly from period 1 values to period 2 values over the period 1910-60. We assumed that mass-balance gradients have been constant prior to 1910 . As the period $1960-90$ is used as a reference period for future scenario calculations, the mass-balance gradients from 1960 onwards are arbitrarily kept constant.

\section{REFERENCE EXPERIMENTS}

\subsection{Tuning to historical glacier-length variations}

Before presenting sensitivity and climate experiments, we will consider the performance of the model. For this purpose, we compare the model results with the historical glacier length with a longitudinal cross-section from 1969, historical volume changes and with observations of the surface velocity around AD 1900.

We used the historical glacier-length record to tune the model, because this is the longest and most reliable record. As tuning parameters, we used the bedrock profile and the flow parameters. From 1882 onwards, we used reconstructed and measured ELAs as forcing as explained in section 4. We reconstructed ELAs for the period prior to 1882 by trial and error, in such a way that the historical length of Rhonegletscher was best simulated. This procedure was developed by Oerlemans (1997) and is called dynamic calibration.

Table 2. Mass-balancegradients. $(\mathrm{d} B / \mathrm{d} z=$ vertical mass-balance gradient; recalculated are corrected values used in the model; $C F$ are values given by Chen and Funk (1990); $n$ is number of observations, $r$ is correlation coefficient; ${ }^{*}$ is value neglected in further analysis). Note that Chen and Funk (1990) only used one mass-balance gradient for the ablation zone but in this study the upper and lower ablation zone were examined separately. See section 4.2 for further explanation

\begin{tabular}{|c|c|c|c|c|c|c|}
\hline \multirow[t]{3}{*}{ Glacier interval } & \multicolumn{3}{|c|}{$\mathrm{d} B / \mathrm{d} z$ period 1 (1884 1908) } & \multicolumn{3}{|c|}{$\mathrm{d} B / \mathrm{d} z$ period 2 (1979 81) } \\
\hline & Data only & Recalculated & $C F$ & Data only & Recalculated & $C F$ \\
\hline & m w.e. $\mathrm{m}^{-1}$ & mw.e. $\mathrm{m}^{-1}$ & $m$ w.e. $m^{-1}$ & mw.e. $\mathrm{m}^{-1}$ & mw.e. $\mathrm{m}^{\prime}$ & m w.e. $\mathrm{m}^{\prime}$ \\
\hline $\begin{array}{l}\text { Accumulation } \\
\text { zone }\end{array}$ & $\begin{array}{c}0.0066^{*} \\
n=30 \\
r=0.44\end{array}$ & 0.0072 & 0.0061 & $\begin{array}{c}0.0061 \\
n=21 \\
r=0.96\end{array}$ & 0.0061 & 0.0063 \\
\hline $\begin{array}{l}\text { Ablation zone } \\
>2100 \mathrm{~m} \text { a.s.l. }\end{array}$ & $\begin{array}{c}0.0078 \\
n=97 \\
r=0.70\end{array}$ & 0.0078 & 0.0092 & $\begin{array}{c}0.0066 \\
n=18 \\
r=0.99\end{array}$ & 0.0066 & 0.0091 \\
\hline $\begin{array}{l}\text { Ablation zone } \\
<2100 \text { m a.s.l. }\end{array}$ & $\begin{array}{c}0.0154 \\
n=23\end{array}$ & 0.0154 & & $n^{*}=0$ & 0.0131 & \\
\hline
\end{tabular}


Using dynamic calibration for the period prior to 1882 , and the measured and reconstructed values of the ELA for the period 1882-1990, we obtained an almost perfect match between modelled and observed glacier-length records (Fig. 8). The only minor drawback is that retreat in the $1940 \mathrm{~s}$ started a little too late. However, the difference between the observed and the modelled glacier lengths is never more than one grid point $(250 \mathrm{~m})$.

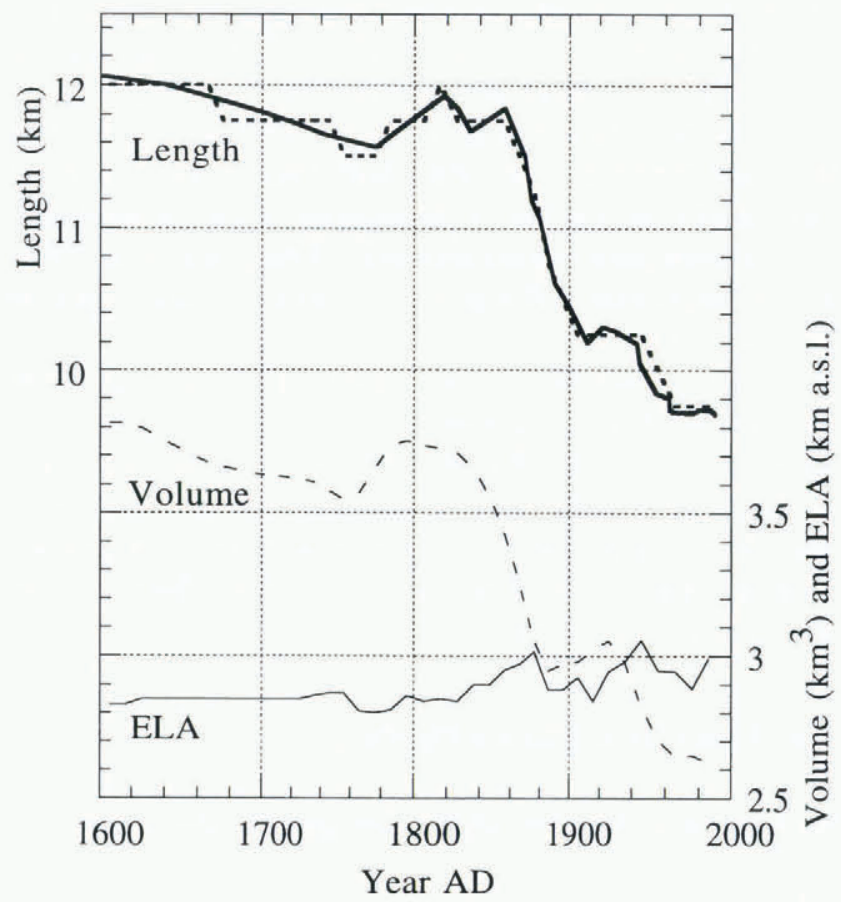

Fig. 8. Left: observed glacier length (solid line) and modelled glacier length (dashed line) since AD 1602. Right: ELA used in the model (solid line) and modelled glacier volume (dashed line).

\subsection{Glacier geometry}

The observed 1969 glacier-surface profile has been compared to the modelled 1969 glacier-surface profile. One can see from Figure 9 that the modelled glacier is too thin at the snout and a little too thick in the middle part. The rms of the difference between observed and simulated surface altitude is $23 \mathrm{~m}$. Although not entirely satisfying, these were the best results that could be obtained without violating the glacierlength record. Since glacier geometry is known from only one snapshot in 1969, correct modelling of the glacier geometry was considered to be of less importance than correct modelling of glacier length, which is known over a far longer period.

As an extra reference experiment, we simulated the historical glacier length and the 1969 glacier geometry using only one mass-balance gradient for the entire glacier. However, this always resulted in a poorer simulation than the reference experiment. This shows that the sub-division into elevation intervals for the mass-balance gradient was indeed justified.

\subsection{Historical volume changes}

Although there is no reliable record of glacier volume over past centuries, some values have been presented by Chen and Funk (1990). According to Chen and Funk (1990), glacier volume decreased by $0.471 \mathrm{~km}^{3}$ in the period 1882

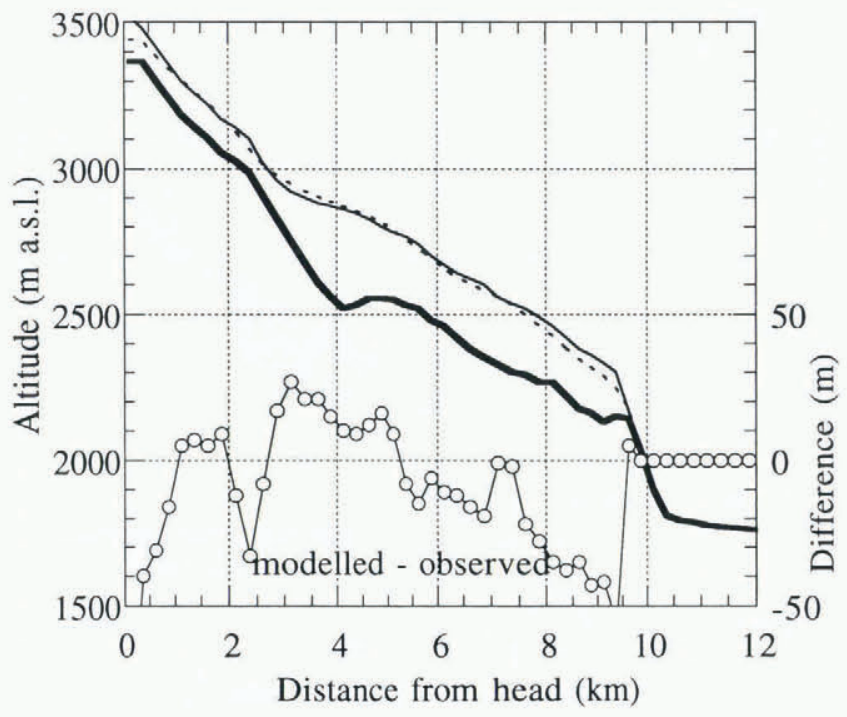

Fig. 9. Observed 1969 surface profile (solid line) and modelled 1969 surface profile (dashed line). Also shown are the differences between modelled and observed surface altitude for each grid point (circles) and the bedrock profile (bold line).

1969. This value was obtained from a comparison of Rhonegletscher surface profiles for 1882 and 1969. Chen and Funk (1990) calculated volume changes from altitude changes times ice-covered surface. The map that Chen and Funk (1990) used for the 1882 situation had been drawn in the period 1874-82 (Mercanton, 1916).

In this study, the volume decrease from 1882 to 1969 is estimated to be only $0.305 \mathrm{~km}^{3}$. This value was obtained by subtracting the modelled glacier volume for 1969 $\left(2.639 \mathrm{~km}^{3}\right)$ from the modelled glacier volume for 1882 $\left(2.944 \mathrm{~km}^{3}\right)$. A possible reason for the difference between the estimate from Chen and Funk (1990) and this research is that they worked with the ice-covered area instead of glacier-surface area. Since the ice-covered area is greater than the glacier-surface area, this will lead to an overestimation of the glacier-volume loss. Another possible explanation is that the 1882 situation presented by Chen and Funk (1990) is not the real 1882 situation but rather the 1874 situation, because surveying for the 1882 map began in 1874. Since the glacier retreated very fast in the period 1874 82 (Fig. 8), a few years of difference can have a large impact on both surface-area and volume estimates. According to our model, the difference in volume between 1874 and 1882 is $0.15 \mathrm{~km}^{3}$, which is almost equal to the difference between the 1882-1969 volume-decrease estimate of Chen and Funk (1990) and our volume-decrease estimate.

\subsection{Glacier-surface velocities}

Surface velocities at various sections of Rhonegletscher for the period 1885-1910 have been given by Mercanton (1916) (Table 3). The measured surface velocities at the flowline are compared to velocities predicted by the model. Modelled velocities have been multiplied by 1.5 to take account of the fact that model velocities are averaged vertically. This factor is based on the equations given by Nye (1965).

The model generally slightly underestimates surface velocities. This difference seems considerable but one should realize that this model captures the three-dimensional geometry only schematically and that longitudinal stresses are 
Table 3. Measured and modelled surface velocities of Rhonegletscher. Measured velocities taken from Mercanton (1916)

Surface velocity in $A D 1900\left(\mathrm{ma}^{\prime}\right)$
Measured

$\mathrm{km}$

\begin{tabular}{lcc}
\hline $3.0-5.0$ & 64 & 55 \\
$5.0-7.5$ & 86 & 87 \\
$7.5-9.0$ & 105 & 89 \\
\hline
\end{tabular}

neglected. It might furthermore be noted that the glacier retreated rapidly around $\mathrm{AD} 1900$. Although this retreat is also captured in the model, it implies that the uncertainty in the modelled velocities due to the precise timing is relatively large. In view of the points mentioned, one should not expect a better performance.

\section{SENSITIVITY EXPERIMENTS}

\subsection{Sensitivity to the forcing parameters}

Before presenting the climate experiments, we explore the sensitivity of the model to variations in input parameters within their estimated uncertainty. As explained in section 4.2, different mass-balance gradients are used for the period prior to 1910 and the period from 1960 onwards. In Figure 10 , steady-state length and steady-state volume are shown for both mass-balance gradients. Mass-balance gradients have little influence on the steady-state length of Rhonegletscher, as long as the ratio between ablation and accumulation gradients is constant, as is the case in this study. Glacier volume, however, is more influenced by mass-balance gradients. Higher gradients lead to a thicker glacier, resulting in a greater volume as can be observed in Figure 10.

From Figure 10, one can see that both steady-state length

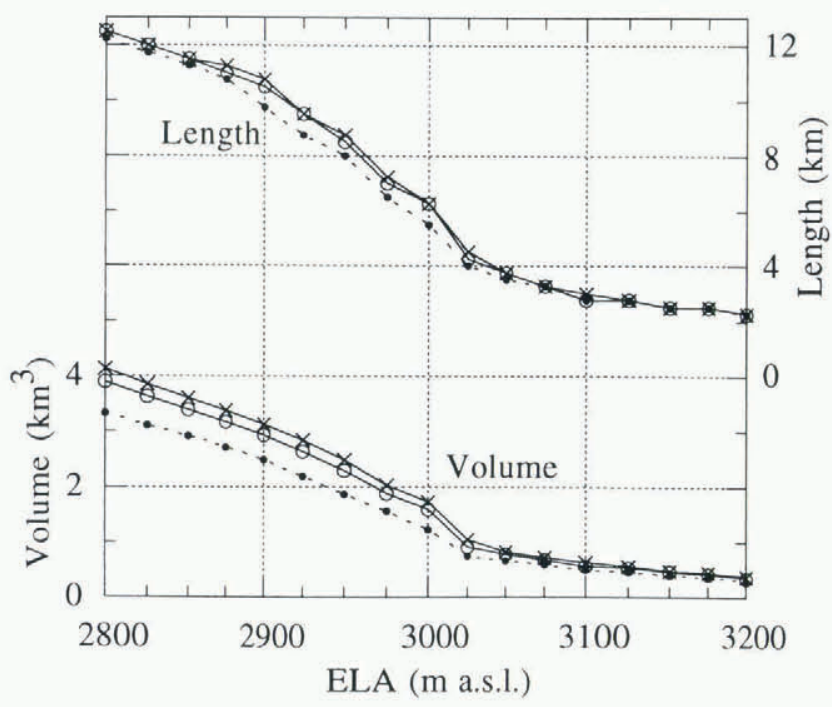

Fig. 10. Sensitivity of steady states of Rhonegletscher to perlurbations of the ELA, mass-balance gradient and flow parameters. Solid lines: mass-balance gradients for the period 1884-1908 (crosses) or mass-balance gradients for the period 197981 (circles) are used. Mass-balance gradients for the first period are 18\% higher than mass-balance gradients for the second period. Dashed line: the flow parameters used are $50 \%$ higher than the standard flow parameters for the second period. and steady-state volume are most sensitive to ELA perturbations in the interval $2900-3025 \mathrm{~m}$ a.s.l. There is a geometrical reason for this, since Rhonegletscher is very wide in this interval. Increasing the ELA from 2900 to $3000 \mathrm{~m}$ a.s.l. yields a volume loss and length change of approximately $40 \%$.

\subsection{Sensitivity to flow parameters and bed profile}

With $50 \%$ higher flow parameters $\left(f_{1}=4.76 \times 10^{25} \mathrm{~m}^{6} \mathrm{~s}^{-1}\right.$ $\mathrm{N}^{-3}, f_{2}=1.43 \times 10^{-18} \mathrm{~m}^{5} \mathrm{~s}^{-1} \mathrm{~N}^{-2}$, glacier length is about $750 \mathrm{~m}$ shorter for ELAs in the interval from 2850 to $3025 \mathrm{~m}$. Glacier volume is about $20 \%$ lower than with default settings, independent of the ELA.

Focusing on the uncertainty in the input parameters means focusing on the bed profile, because the bed profile is partly reconstructed and not measured (Fig. 3). To investigate the sensitivity of the glacier to different bed profiles, we compared steady-state profiles of Rhonegletscher for four different bed profiles. Three of the bed profiles used were achieved by different smoothing functions over the bed profile constructed on the assumption of constant basal shear stress (section 2). In the standard run, a smoothing of $70 \%$ was used. A smoothing of $80 \%$ resulted in a shallow trench, whereas a smoothing of $60 \%$ resulted in a deep trench (Fig. 11). The bed profile presented by Stroeven and others (1989) was also used as input (Fig. 11). The ELA is adjusted in such a way that the rms of the difference between modelled surface and observed 1969 surface was minimal for the standard bed. To calibrate the model for the different bed profiles (minimizing rms between observed and modelled surface), we adjusted the flow parameter $f_{1}$. Note that equilibrium profiles are compared to the 1969 profile, which is only in near-equilibrium state.

From the experiment, it is concluded that considerable changes in bed profile have only little effect on the surface profile after calibration with flow parameter $f_{1}$ (Fig. 11; Table 4). It might further be noted that, after calibration, the surface velocity varies only marginally for the three trenches studied. The bed profile used in this study gives better results than the bed profile used by Stroeven and others (1989) on both geometry and surface velocity.

Table 4. Bed profiles, parameters used in the experiment and results of the experiment. Note that modelled equilibrium profiles are compared to the 1969 observed profile. Flow parameters for the standard run have not been adjusted; other scenarios have been calibrated with $f_{1}$. This explains the lower rms for the shallow trench and deep trench scenarios. Note that Stroeven and others (1989) used a different mass-balance formulation

\begin{tabular}{lcccc}
\hline $\begin{array}{l}\text { Bed profile } \\
\text { ELA }\end{array}$ & $f_{1}$ & $\begin{array}{c}\text { Normalized } \\
\text { surface velocity } \\
\mathrm{km} 3109\end{array}$ & $\begin{array}{c}\text { rms difference } \\
\text { observed- } \\
\text { modelled surface }\end{array}$ \\
& ma.s.l. & $10^{17} \mathrm{~m}^{6} \mathrm{~N}^{-3} \mathrm{a}^{-1}$ & $\mathrm{~m} \mathrm{a}^{-1}$ & $\mathrm{~m}$ \\
\hline $\begin{array}{l}\text { This study } \\
\text { Shallow trench }\end{array}$ & 2910 & 1.0 & 1.00 & 21.2 \\
$\begin{array}{l}\text { Deep trench } \\
\text { Stroeven and } \\
\text { others (1989) }\end{array}$ & 2910 & 1.3 & 1.04 & 20.8 \\
& 2910 & 1.0 & 0.97 & 21.0 \\
\hline
\end{tabular}




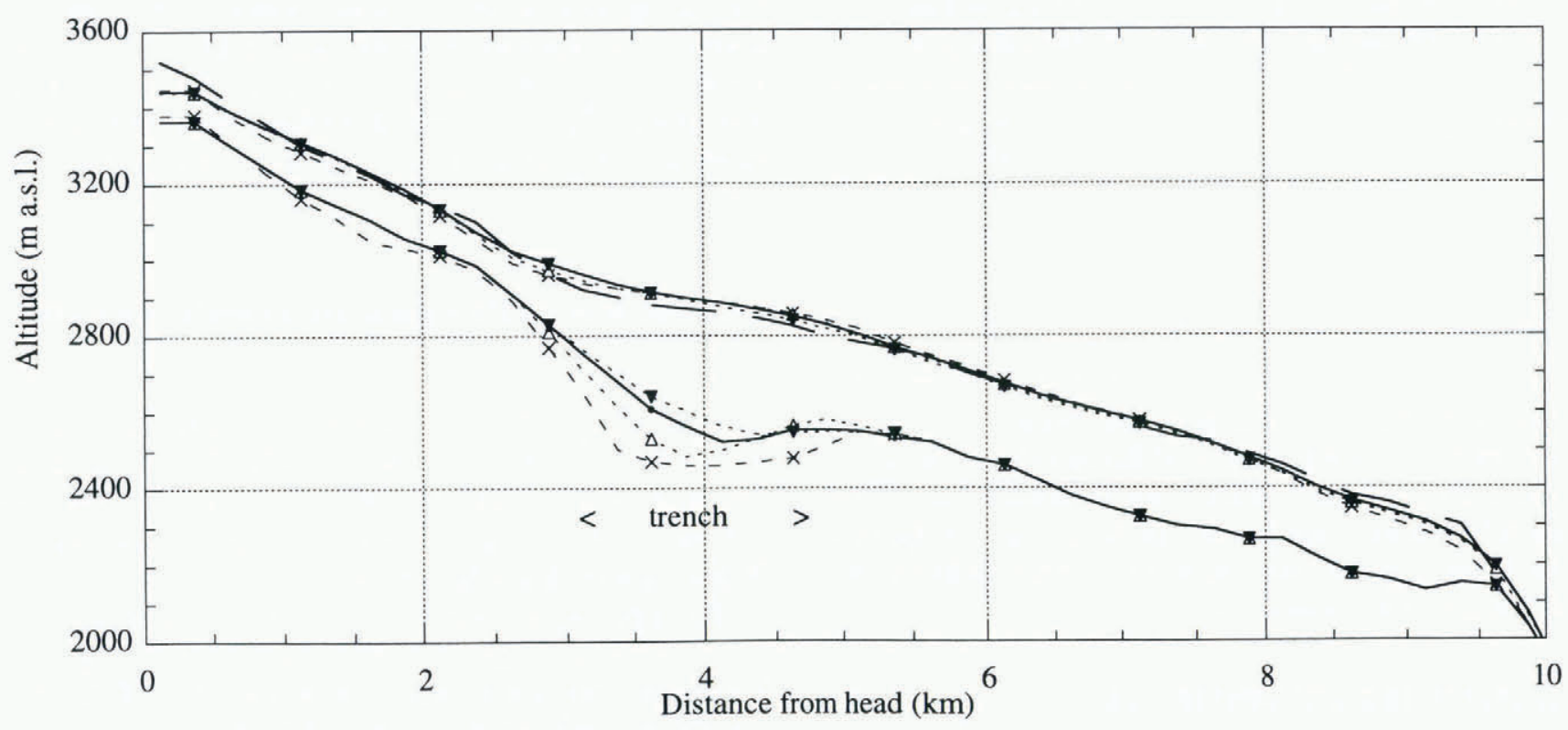

Fig. 11. Different bed profiles and resulting surface profiles after calibration with flow parameter $f_{1}$. Upper bold dashed line: observed 1969 surface profile. Solid lines: standard bed profile and resulting surface profile. Dashed lines: shallow trench experiments (closed triangle markers), deep trench experiments (open triangle markers) and experiment with bed profile from Stroeven and others (1989) (crosses). Note that the differences in the surface profiles are very small.

\section{GLIMATE-GHANGE EXPERIMENTS}

The goal of this study is to quantify the response of Rhonegletscher to enhanced greenhouse warming. The response is investigated by running the model until the year AD 2100 for seven climate-change scenarios. The 1961-90 period is taken as reference period. The mean summer air temperature for this period averaged from Reckingen and Andermatt is $12.0^{\circ} \mathrm{C}$ and the mean ELA for this period is $2942 \mathrm{~m}$ a.s.l. The ELA-temperature correlation shown in section 4 is used to construct the ELA for the period 1991-2100. Influence of precipitation changes was estimated by Oerlemans (personal communication, 1996) using a mass-balance model of Rhonegletscher. He obtained a $57 \mathrm{~m}$ drop in the ELA for a $10 \%$ increase in annual precipitation. This value matches the results of studies in Norway (Oerlemans, 1992). The mass-balance gradient may vary systematically with precipitation increase relating to future climate scenarios. However, present data on both parameters are insufficient to obtain a statistical relationship between precipitation and mass-balance gradient. Therefore, the mass-balance gradients given for period 2 in Table 2 are used for all scenarios.

The response of the ELA and the mean specific balance

Table 5. Instantaneous changes of climate in 1990 and reaction of the ELA and mean specific balance (M) in 1991. $\mathrm{d} E L A$ and $\mathrm{d} M$ are relative to the 1991 situation without climate change

\begin{tabular}{rrrrrc}
\hline $\begin{array}{c}\text { Climate change } \\
\mathrm{d} T_{\mathrm{s}}\end{array}$ & $\mathrm{d} P$ & ELA & $\mathrm{d} E L A$ & $M$ & $\mathrm{~d} M$ \\
$\mathrm{~K}$ & $\%$ & m a.s.l. & $\mathrm{m}$ & $\mathrm{m}$ w.e. & m w.e. \\
\hline 0 & 0 & 2942 & 0 & -0.13 & 0 \\
+1 & 0 & 3069 & 127 & -0.93 & -0.80 \\
0 & +10 & 2885 & -57 & 0.22 & 0.35 \\
+1 & +10 & 3012 & 70 & -0.57 & -0.44 \\
\hline
\end{tabular}

$(M)$ of Rhonegletscher to climate change is given Table 5. The effect of a $1 \mathrm{~K}$ warming could almost be compensated by a $20 \%$ increase in precipitation. According to Kattenberg and others (1996), a much smaller increase in precipitation with climate warming is expected for the Alps. Therefore, climate warming will lead to increased melt and the retreat of Rhonegletscher. Climate-change scenarios and the response of length and volume of Rhonegletscher are shown in Table 6 and in Figure 12.

From Table 6 and Figure 12, it follows that Rhonegletscher is almost in equilibrium with the 1961-90 climate. With no climate change from 1991 to 2100 , relative to the 1961-90 mean, $94 \%$ of the glacier volume will be preserved by $\mathrm{AD} 2100$. With a warming rate of $0.04 \mathrm{~K} \mathrm{a}^{-1}$ and no change in precipitation, only $4 \%$ of the glacier volume will be preserved by $\mathrm{AD} 2100$. With this last scenario, Rhonegletscher will ultimately vanish completely, because the equilibrium line will be located above the top of the glacier by AD 2100 .

We have used dynamic calibration to force the glacier in the right mode at the beginning of the measured and reconstructed forcing record and to obtain the correct glacier length for the present day. To investigate how important this

Table 6. Climate-change scenarios and response of Rhonegletscher to climate change

\begin{tabular}{ccccccc}
\hline Scenario & $\begin{array}{c}\text { Warming } \\
\text { rate }\end{array}$ & $\begin{array}{c}\text { Precipi- } \\
\text { tation } \\
\text { change }\end{array}$ & $\begin{array}{c}\text { Glacier } \\
\text { length in } \\
\text { AD } 2100\end{array}$ & $\begin{array}{c}\text { Scaled } \\
\text { length } \\
2100 / 1990\end{array}$ & $\begin{array}{c}\text { Glacier } \\
\text { volume in } \\
\text { AD 2100 }\end{array}$ & $\begin{array}{c}\text { Scaled } \\
\text { volume } \\
2100 / 1990\end{array}$ \\
& $\mathrm{~K} \mathrm{a}^{-1}$ & $\mathrm{~km}$ & & $\mathrm{~km}^{3}$ & \\
\hline 1 & 0 & & 8.75 & 0.92 & 2.42 & 0.94 \\
2 & 0.01 & 10 & 8.25 & 0.87 & 1.99 & 0.77 \\
3 & 0.01 & & 7.75 & 0.82 & 1.63 & 0.63 \\
4 & 0.02 & 10 & 7.50 & 0.79 & 1.55 & 0.60 \\
5 & 0.02 & & 5.75 & 0.61 & 0.89 & 0.34 \\
6 & 0.04 & 10 & 5.50 & 0.58 & 0.75 & 0.29 \\
7 & 0.04 & & 2.25 & 0.24 & 0.11 & 0.04 \\
\hline
\end{tabular}




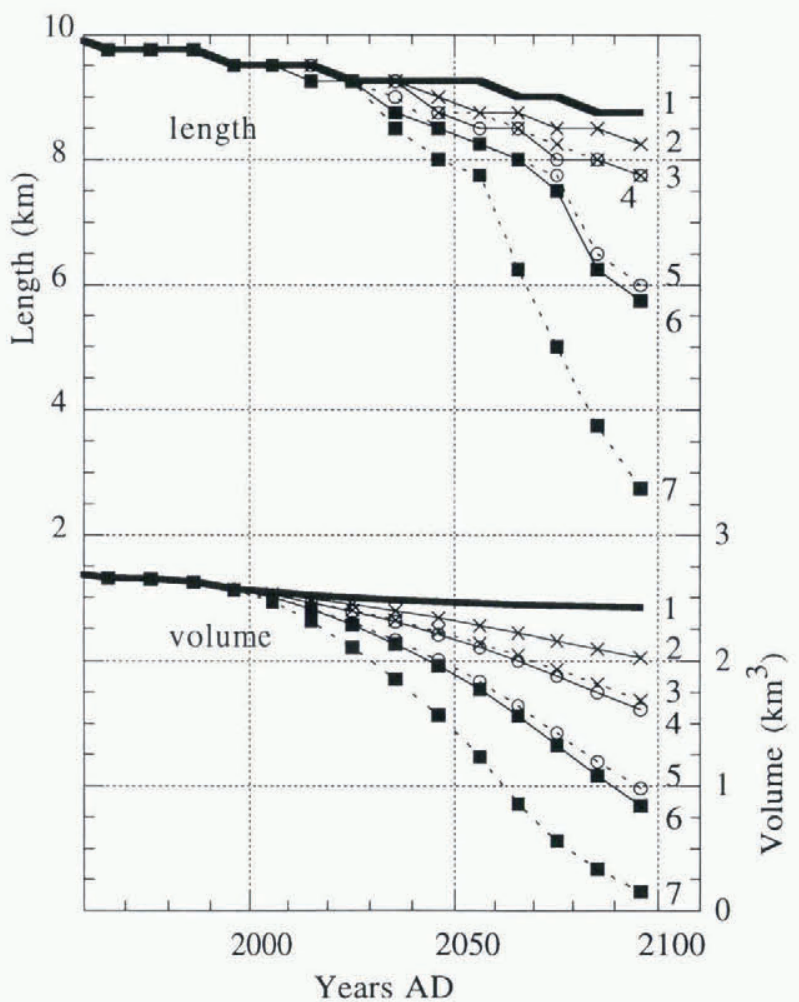

Fig. 12. Length and volume for the climate-change scenarios for Rhonegletscher. Numbers denote climate-change scenario used. See Table 7 for a description of the climate-change scenarios.

dynamic calibration is for the final results, we have carried out some experiments. The main question is whether the scaled 2100/1990 glacier length and volume would be different if the glacier was not forced in the retreating mode at the end of the nineteenth century. To answer this question, we carried out a run with the glacier in an equilibrium state in 1880 using the 1880 observed length. From 1882 onwards, the same forcing with the ELA was used as in the standard experiment. Glacier response was tested for scenarios 1 (no change) and $3\left(0.02 \mathrm{~K} \mathrm{a}^{-1}\right)$. In addition to these experiments, we carried out a run with the glacier in an equilibrium state in 1990, using the observed 1990 glacier length. We used the same two scenarios as with the 1880 equilibrium run. The results from these two experiments are given in Table 7. Glacier response for these scenarios without climate warming (scenario 1) is shown in Figure 13.

From Table 7 and Figure 13, it is concluded that the results vary only slightly for experiments with and without dynamic calibration prior to 1882 , and without climate forcing prior to 1990 . For the experiment with a steady state in 1880 , this is caused by the long period of more than 100 years with climate forcing. Although Rhonegletscher

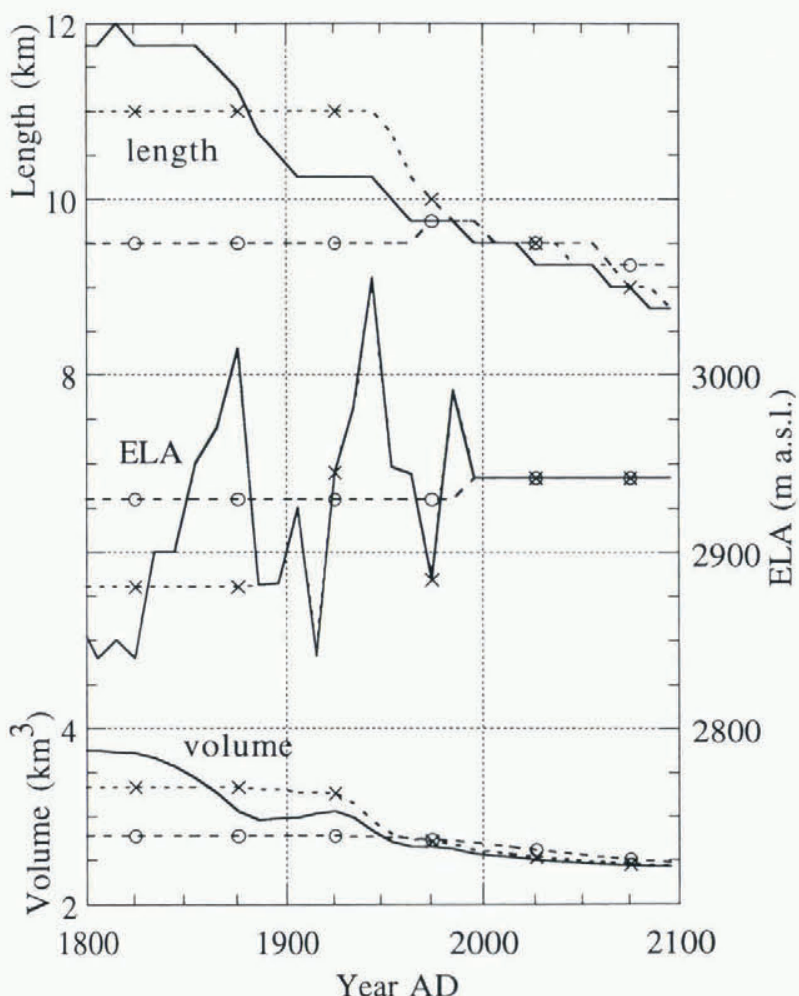

Fig. 13. Glacier length and volume as well as the forcing ELA for the standard run ( solid line), without dynamic calibration prior to 1882 (crosses) and without climate forcing prior to 1990 (circles). See section 7 and Table 7 for explanation.

was far from an equilibrium state in 1880, the period between 1880 and 1990 is long enough for the glacier to get close to its "normal" state in 1990. The small differences between the standard experiment and the experiment with a 1990 steady-state glacier are a consequence of the nearequilibrium state of Rhonegletscher in 1990.

\section{DISCUSSION}

The Rhonegletscher model simulates glacier length and geometry satisfactorily. A drawback of the model is that it underestimates surface velocities by about $1-18 \%$. The reasons for this underestimation are not entirely clear. Larger flow parameters do not help to solve this problem, because larger flow parameters lead to a thinner glacier, resulting in lower surface velocities. The underestimation of surface velocities by the model may be related to the fast retreat of Rhonegletscher in the measurement period. However, it should also be realized that a vertically integrated flow model with a schematic three-dimensional crossprofile is only a coarse approximation of reality with variations in velocity in three dimensions. As most of these one-

Table 7. Results of climate-change experiments with and without dynamic calibration. Standard: dynamic calibration prior to 1882, climate forcing from 1882 onwards. 1990 steady: glacier in a steady state in 1990. 1880 steady: glacier in steady state in 1880, climate forcing from 1882 onwards

\section{Warming rate} (1991-2100)
Scaled glacier length (2100/1990)

1990 steady
Scaled glacier volume (2100/1990)

Standard

1880 steady
1990 steady

\begin{tabular}{llllllll}
$0 \mathrm{~K} \mathrm{a}^{-1}$ & 0.92 & 0.95 & 0.90 & & 0.94 & 0.91 \\
$0.02 \mathrm{~K} \mathrm{a}^{-1}$ & 0.61 & 0.62 & 0.62 & 0.34 & 0.34 & 0.34 \\
\hline
\end{tabular}


dimensional flow models lack a good comparison of modelled and measured velocities, it is not feasible to expect more accuracy in this respect.

Comparison of mass-balance measurements taken in the periods 1884-1908 and 1979-81 shows that the mass-balance gradients have changed with time. Although used in the model, these measurements should be used with caution. Measurements in the second period were made only over 3 years. Those 3 years had an exceptional high precipitation, compared to the 1961-90 mean (Müller-Lemans and others, 1995). According to Oerlemans (1992), mass-balance gradients are larger for warmer and more humid climates. In this study, the opposite seems to be true. However, there are too few data to establish correlations between annual precipitation, summer air temperature and annual massbalance gradients.

For Rhonegletscher, varying of mass-balance gradients within the measurement uncertainty has only small effects on the glacier length (Fig. 10). This is a consequence of the ratio between accumulation area and ablation area, which for Rhonegletscher is close to 1. For glaciers with an accumulation/ablation area ratio that is greater than 1, greater mass-balance gradients tend to enforce response of the glacier snout to climate change. This was observed, for instance, at Nigardsbreen, Norway (Oerlemans, 1992).

The average annual mean specific mass balance for Rhonegletscher for the 1850-1970, according to our model, is $0.39 \mathrm{mw}^{\mathrm{e}} \mathrm{a}^{-1}$. This is not far from the value of $0.31 \mathrm{~m}$ w.e. $\mathrm{a}^{-1}$ needed by Haeberli and Hoclzle (1995) to match the Rhonegletscher retreat from the 1850 steady-state length to the 1970 steady-state length. It should be noted, however, that the use of steady states to interpret glacier characteristics from inventory data (e.g. Haeberli and Hoelzle, 1995) will only lead to reasonable results, if the glacier is in near-equilibrium state at both the start and the end of the period under study. In other circumstances, serious misinterpretation of results might occur.

In this study, dynamic calibration is used to reconstruct ELAs for the period for which no reliable climate data exist. Dynamic calibration was not crucial for the results of the experiments in this study, because of the long climate record relative to the response time of the glacier. However, dynamic calibration can be an important tool in glacier modelling, especially when there is only a short climate record in comparison to the response time of the glacier, or when the glacier is far from an equilibrium state at the beginning of the record. In these cases, dynamic calibration helps to extend the forcing record, thereby reducing the risk of misinterpretation of results.

\section{CONCLUSIONS}

The climate-change experiments have shown that Rhonegletscher is almost in equilibrium with the 1961-90 climate. With no climate change relative to the $1961-90$ period, $94 \%$ of the glacier's volume will be preserved by AD 2100 . With a climate-warming rate of $0.04 \mathrm{~K} \mathrm{a}^{-1}$, Rhonegletscher will vanish in 100 years. The effect of a temperature increase of $1 \mathrm{~K}$ could be compensated by a $20 \%$ increase in precipitation. However, since such a precipitation increase is generally thought to be improbable, climate warming will certainly lead to further melting of Rhonegletscher.

\section{ACKNOWLEDGEMENTS}

We are grateful to W. Eckert for providing climatic data from Grimsel and Andermatt for the years 1987-90, to M. Funk for information enabling us to reconstruct temperatures from Reckingen for the years 1987-90, and to J. Oerlemans for providing data regarding the sensitivity of Rhonegletscher to precipitation changes. Furthermore, we wish to thank all participants of the EISMINT workshop in Pontresina (Switzerland), 16-18 October 1996, in particularly A. Stroeven for his critical comments on the manuscript. We highly appreciated the constructive reviews by W. Haeberli and G. H. Gudmundsson, and by an anonymous reviewer; their comments helped us to improve this paper. S. MacNab has patiently corrected the English text. This work is sponsored by the ESF/EISMINT (European Ice Sheet Modelling Initiative, a programme of the European Science Foundation).

\section{REFERENCES}

Aellen, M. 1981. Recent fluctuations of glaciers. In Kasser, P. and W. Haeberli, eds. Switzerland and her glaciers: from the ice age to the present. Zürich, Swiss National Tourist Office (SNTO) and Kümmerly and Frey, $70-89$.

Bider, M., M. Schüepp and H. von Rudloff. 1959. Die Reduktion der 200jährigen Basler Temperaturreihe. Arch. Meteorol. Geophys. Bioklimatol., Ser. $B, 9,360-412$

Bindschadler, R. 1981. The predicted behavior of Griesgletscher, Wallis, Switzerland, and its possible threat to a nearby dam. Z. Gletscherkd. Glazialgeol., 16 (1), 1980, 45-59.

Bindschadler, R. 1982. A numerical model of temperate glacier flow applied to the quiescent phase of a surge-type glacier. f. Glaciol., 28 (99), 239- 265.

Budd, W. F., P. L. Keage and N. A. Blundy. 1979. Empirical studies of ice sliding. J. Glaciol., $23(89), 157-170$.

Burkhardt, T. and A. Hense. 1985. On the reconstruction of temperature records from proxy data in mid-Europe. Arch. Meteorol. Geophys. Bioklimatol., Ser. B, $35(4), 341-359$.

Chen, J. and M. Funk. 1990. Mass balance of Rhonegletscher during 1882 83-1986/87. 7. Glaciol., 36(123), 199-209.

Greuell, W. 1989. Glaciers and climate: energy balance studies and numerical modelling of the historical front variations of the Hintereisferner (Austria). (Ph.D. thesis, Utrecht University.)

Greuell, W. 1992. Hintereisferner, Austria: mass-balance reconstruction and numerical modelling of the historical length variations. F. Glaciol., 38 (129), 233-244.

Haeberli, W., comp. 1985. Fluctuations of glaciers 1975-1980 (Vol. IV). Paris, International Commission on Snow and Ice of the International Association of Hydrological Sciences/Unesco.

Haeberli, W. and M. Hoelzle, comps. 1993. Fluctuations of glaciers 1985-1990 (Vol.VI). Wallingford, Oxon, IAHS Press; Nairobi, UNEP; Paris, Unesco.

Haeberli, W. and M. Hoelzle. 1995. Application of inventory data for estimating characteristics of and regional climate-change effects on mountain glaciers: a pilot study with the European Alps. Ann. Glaciol., 21, 206-212.

Haeberli, W. and P. Müller, comps. 1988. Fluctuations of glaciers 1980-1985 (Vol. V). Wallingford, Oxon., IAHS Press; Nairobi, UNEP; Paris, Unesco.

Huybrechts, P., P. de Nooze and H. Decleir. 1989. Numerical modelling of Glacier d'Argentiére and its historic front variations. In Oerlemans, J., ed. Glacier fluctuations and climatic change. Dordrecht, etc., Kluwer Academic Publishers, 373- 389.

Jost, W. 1936. Die seismischen Eisdickenmessungen am Rhonegletscher 1931. Denkschr. Schweiz. Naturforsch. Ges., 71 (2).

Kasser, P. 1967. Fluctuations of glaciers $1959-1965$ Vol. I]. Paris, International Commission of Snow and Ice of the International Association of Scientific Hydrology/UNESCO.

Kasser, P. comp. 1973. Fluctuations of glaciers 1965-1970 Vol. II]. Paris, International Commission on Snow and Ice of the International Association of Hydrological Sciences/UNESCO.

Kattenberg, A. and 8 others. 1996. Climate models: projections of future climate. In Houghton, J. T., L. G. M. Filho, B. A. Callander, N. Harris, A. Kattenberg and K. Maskell, eds. Climate change 1995: the science of climate change. Cambridge, etc., Cambridge University Press, 285-357.

Kruss, P. 1983. Climate change in East Africa: a numerical simulation from the 100 years of terminus record at Lewis Glacier, Mount Kenya. Z 
Gletscherkd. Glazialgeol., 19 1), 43-60.

Kruss, P. 1984. Terminus response of Lewis Glacier, Mount Kenya, Kenya, to sinusoidal net-balance forcing. F. Glaciol., 30(105), 212-217.

Lamb, H. H. 1977. Climate: present, past and future. Vol. 2: Climatic history and the future. London, Methuen.

Meier, M. F. 1965. Glaciers and climate. In Wright, H. E., Jr and D. G. Frey eds. The Quaternary of the United States. Princeton, NJ, Princeton University Press, 795-805.

Mercanton, P.-L., ed. 1916. Vermessungen am Rhonegletscher / Mensuration au glacier du Rhòne: 1874-1915. Neue Denkschr. Schweiz. Naturforsch. Ges. 52

Müller, F., comp. 1977. Fluctuations of glaciers $1970-1975$ (Vol. III). Paris, International Commission on Snow and Ice of the International Association of Hydrological Sciences/Unesco.

Müller-Lemans, H., M. Funk, M. Aellen and G. Kappenberger. 1995. Langjährige Massenbilanzreihen von Gletschern in der Schweiz. Z Gletscherkd. Glazialgeol., 30, 1994, 141-160.

Nye, J. F. 1965. The flow of a glacier in a channel of rectangular, elliptic or parabolic cross-section. J. Glaciol., 5 (41), 661-690.

Oerlemans, J. 1986. An attempt to simulate historic front variations of $\mathrm{Ni}$ gardsbreen, Norway. Theor. Appl. Climatol., 37 (3), 126-135.

Oerlemans, J. 1992. Climate sensitivity of glaciers in southern Norway: application of an energy-balance model to Nigardsbreen, Hellstugubreen and Alfotbreen. 7. Glaciol., 38 129), 223-232.

Oerlemans, J. 1997. A flowline model for Nigardsbreen, Norway: projection of future glacier length based on dynamic calibration with the historic record. Ann. Glaciol., 24, 382-389.

Oerlemans, J. and J. P. F. Fortuin. 1992. Sensitivity of glaciers and small ice caps to greenhouse warming. Science, 258 (5079), 115-117.

Oerlemans, J. and 10 others. 1998. Modelling the response of glaciers to climate warming. Climate Dyn., 14, 267-274.

Paterson, W. S. B. 1981. The physics of glaciers. Second edition. Oxford, etc., Pergamon Press.

Pfister, C. 1984. Klimageschichte der Schweiz 1525-1860. Acad. Helvetica, 6 (1)

Schmeits, M.J. and J. Oerlemans. 1997. Simulation of the historical variations in length of Unterer Grindelwaldgletscher, Switzerland. J. Glaciol. $43(143), 152-164$.

Stroeven, A., R. van de Wal and J. Oerlemans. 1989. Historic front variations of the Rhone Glacier: simulation with an ice flow model. In Oerlemans, J., ed. Glacier fluctuations and climatic change. Dordrecht, etc., Kluwer Academic Publishers, $391-405$.

Wächter, H.-P. 1983. Eisdickenmessungen auf Alpengletschern. Das Gelbe Heft (Zurich), 1983, 21-22.

Warrick, R. A., C. le Provost, M. F. Meier, J. Oerlemans and P. L. Woodworth. 1996. Changes in sea level. In Houghton, J.T., L. G. M. Filho, B. A. Callander, N. Harris, A. Kattenberg and K. Maskell, eds. Climate change 19.95: the science of climate change. Cambridge, etc., Cambridge University Press, 359-405.

Zuo, Z. and J. Oerlemans. 1997. Numerical modelling of the historic front variation and the future behaviour of the Pasterze glacier, Austria. Ann. Glaciol., 24, $234-241$.

MS received 23 June 1997 and accepted in revised form 1 February 1998 